\title{
The Role of social Identity in James Joyce`s Dubliners within the Light of Cultural Materialism
}

\author{
Mojgan Gaeini ${ }^{1}$, Fatemeh Sadat Basirizadeh ${ }^{2}$, Mahnaz Soqandi MA ${ }^{3}$ \\ ${ }^{1}$ Islamic Azad University, Qom Branch, Qom, Iran \\ ${ }^{2}$ Young Researchers and Elite Club, Qom Branch, Islamic Azad University, Qom, Iran \\ ${ }^{3}$ Student in English Literature, English Language and literature Department, Faculty of Humanities, Semnan \\ University, Semnan, Iran \\ Imojgan.Gaeini@gmail.com, ${ }^{2}$ nbasiri2002@yahoo.com
}

\begin{abstract}
Language, Social identity and Religion are three major concerns of cultural studies. Language in literary texts plays a major role in constructing meaning and reflecting the author's intention. Likewise religion as a cultural politics is a dominant factor in shaping mind as well in affecting the framework of literary text. Religion is one of the emerging issues in the modern era and forms the backbone of most literary works. Religion as a theme is seen to influence the operation of those who believe in it. It forms the functional framework that predetermines ones actions and behavior. Furthermore, social identity decides on the status of the social class and their material life situation. Social identity relates to how we identify ourselves in relation to others according to what we have in common. All these issues are interrelated since they all cooperate and construct a social and cultural materiality. James Joyce could be placed among the most dominant cultural authors whose concern is the material life, social class, social identity and cultural crisis. As an outstanding author, Joyce is well known for his typical depiction, musical decoration as well as his sticking to proper cultural and social materials and issues such as religious matters. His major short story collection, Dubliners, revolves around the lifestyle of the Irish middle-class in Dublin around the late 1800s and early 1900s. This collection is decorated with violated norms and ritualistic behavior that are part of social constructs. Addressing social, religious and cultural issues, cultural materialists believe that "literature can serve as an agent of change", since a culture's hegemony is unstable. Raymond Williams views culture as a "productive process" that is, part of the means of production, and cultural materialism often identifies what he called "residual", "emergent" and "oppositional" cultural elements. Seemingly, James Joyce's Dubliners pertains to the notion of language, social identity and religion as cultural practices within the framework of cultural materialism. This study aims to clarify how James Joyce's Dubliners reflects the notions of language, social identity and religion as cultural practices and how they construct social and cultural products within the framework of cultural materialism to show how James Joyce criticizes Irish culture at the beginning of the Twentieth century.
\end{abstract}

Keywords : Cultural Materialism; Social Identity; Language; Religion; Infrastructure

\section{Introduction}

The aim of this paper is to examine the role of social identity in the theory cultural materialism in the light of Raymond Williams. Specifically, to: (1) examine the combined effects of self-identity and social identity constructs on intention and behavior, and (2) examine the effects of self-identity as a function of past experience of performing the behavior. The selected stories of Dubliners are discussed in this chapter are as follows: "The Sisters", "A little Cloud" ,"An Encounter", "Araby", The Dead", "A Mother ", "The Boarding House" and "Counterparts". 
James Joyce has already been read as a migrant writer; however, Dubliners has not been considered as being an important contribution to this mode of writing. In this chapter, Postcolonial of identity, relationship to local culture are used in an in-depth reading of six of the stories in the collection which the researcher argues are written in the lack of identity mode of writing. The social identity examines within Dubliners. The researcher will studied Dubliners as a book that delineates and explores the dominance of universal paradigms such as religion and the family within the formation of identity, and the crisis of identity coming to terms with the expectations of a given society. Particularly, Dubliners portrays an Irish society which is attempting to come to terms with its own verifiable crisis. Dubliners was published in 1914, the year that brought the First World War and the greatest material and spiritual crisis Europe had faced. The stories in Dubliners were written when Irish patriotism was bustling in its drive for an intact, independent identity. Challenge for Irish identity also required a reinvention, and the researcher will argue that this necessity is taken by Joyce in his use of the "epiphany." The stories of Dubliners tend to end with a moment of clarity or self-understanding regarding a obligation, a comprehension of an action or desire, or an awareness of a necessary course of action. Dubliners goes deeper than metaphors for a war for independence or the search for a combined national identity. The researcher argues that Joyce identifies, through everyday examples, the basis structures in society which contribute to a crisis in identity.

\section{Review of Literature}

To Raymond Williams, the nation-state was basically an institution of cultural modernity and imperialism. In his major work, The Country and the City (1973), he tried an investigation of the connections that exist between the capitalist order and the nation state. The idealization of one particular class was accompanied by a mystification of national interest and national identity. Opening with a look at the genre of country house writing, Williams was interested in how this writing both reflected the power of a late feudal aristocracy and actively contributed to augmenting its power. Williams explores the connection between a mystified social capitalist order and an equally mystified concept of national identity and national interest. Williams's opposition to the imperial social order abruptly exposes the breakup of the empire and the breakup of the union to be part of the same process.

By imagining a Wales struggling for self-rule as early as 1978 , Williams attempted to raise the levels of Welsh self-consciousness to a sufficiently high level for self-rule to become a reality in the 1979 devolution referendum. The „no vote in 1979 followed by the eventual ,yes ${ }^{\text {ee }}$ in 1997 shows that, all the time, this critical consciousness was on the rise. Devolution itself is an ongoing process, rather than an accomplished fact. As a result of his prescience into that process, Williams is a major figure in our understanding of postcolonial British cultures.

Raymond Williams declared these twin elements of his work for Welsh consciousness when he wrote:

The central point about Scottish and Welsh nationalism is perhaps this: that in Scotland and Wales we are beginning to find ways of expressing two kinds of impulse that are in fact very widely experienced throughout British society. First, we are trying to declare 
an identity, to discover in fact what we really have in common, in a world which is full of false identities... And second, but related to this, we are trying to discover political processes by which people really can govern themselves - that is, to determine the use of their own energies and resources - as distinct from being governed by an increasingly centralized, increasingly remote and also increasingly penetrating system: the system that those who run it, for their own interests, have decided to call "Unity."( Who Speaks for Wales 188)

The process of discovering an identity, we might say, is in part the work of fiction and cultural production. The demand for politically separatist institutions then belongs to the more strictly political sphere. Yet Williams does not draw such a tight demarcation between the two. Instead, he makes an argument about the relation of culture and politics that is openly dialectical and mutually determining. Separatist political institutions create the conditions under which it becomes possible for Scotland and Wales to support their own cultural production: their own writers, dramatists and artists. At the same time, it is also partly because those cultural figures have the courage and confidence to explore their own identity with differential regard to the British whole that the nations in question develop the self-confidence required to demand political institutions of representation. In a way, therefore, Williams was campaigning for Welsh devolution while sitting at his desk writing novels. These contributed somewhat to the general rise in Welsh consciousness during the period 1979-97 ( Dix qtd . in Raymond Williams, Cultural Materialism 13).

In The "Culture of Nations"e Williams draws attention to a deeper theoretical problem:

The most active legal (and communal) defence of dislocated and exposed groups and minorities is essential. But it is a serious misunderstanding, when full social relations are in question, to suppose that the problems of social identity are resolved by formal definitions. For unevenly and at times precariously, but always through long experience substantially, an effective awareness of social identity depends on actual and sustained social relationships. To reduce social identity to formal legal definitions, at the level of the state, is to collude with the alienated superficialities of ,the nation "e which are the limited functional terms of the modern ruling class.( Towards 195)

In one sense Williams could be said to be too keen to overlook the hard-won recognition and legal equality gained by members of Britain ${ }^{\text {ee }}$ immigrant population in the years after 1945 .

Raymond Williams can be understood as an early postcolonial writer, in the very particular sense that he anticipates the moment of devolution and the political break-up of Britain. His own novels have then to be understood as part of a much more general process of questioning the received unitary identity of Britain, which occurs along all sorts of other coordinates.

Irish identity and culture were considered to stress on the themes reflecting reality such as paralysis, helplessness, loneliness, death and religion. Psychoanalytic criticism analyzes literature for meaning as one would inspect a dream; it highlights recurrent story plots and character types, which deeply affects the reader, awaking images of the collective unconscious. These psychoanalytic ideas had a unique contribution to explore the depth of a 
literary work and by doing so understanding the society reflected in the literary work (Brandell 41). The Themes of immigration and poverty are two of the most important variation of themes in Irish fiction; as they reflect the changing dynamics of contemporary Dublin (Kilroy 15). The troubles in Northern Ireland discouraged foreign investment causing the stagnation of Irish Economy. The state of instability lasted till the late 1980's and as soon as the European community started to invest, the economic growth rates began reaching a high level.

\section{Discussion}

\subsection{The Role of social Identity in The Sisters}

Joyce's work suggests that a critique of culture and its structures is important, as family and religious structures are shown to be preserving a religious and ethical paralysis in individuals. The characters of Dubliners strive to name a believable truth on their lives. Social conformity commands that the individual employs the established beliefs of society. Accordingly, the completion or practice of knowledge is itself established upon illusion. Language and illusion are combined and practiced for the purpose of ideology, principally that of the big Other. There are ideological structures in place which support the perpetuation of such practices across generations, such as the concept of a nationality or morality, which usually take the form of a state or a religion-Capitalism, Marxism, Catholicism. These play a vital role in shaping and determining the identity of an individual. As Louis Althusser puts it, "individuals are always-already interpellated by ideology as subject" (Althusser 1971, 164).

Numerous characters in Dubliners suffer from paralysis that influences their capacity to alter their lives and break there circle of schedule that concede their dreams. One case of a character in a state of paralysis is the most character in "The Sisters". In "The Sisters," Joyce portrays the self as a development, both of the self and of the recognition of the other. The characters' conceptions of themselves and of others, especially those of the youthful storyteller and Father James Flynn, are more than once destabilized. One example of a character in a state of paralysis is the main character in "The Sisters". The death of Father Flynn waits with the youthful boy causing him to slip in a state of paralysis. Like numerous of the stories, this story is or maybe equivocal and the creator takes off out numerous points of interest which comes about in a few things being cleared out unexplained. When the youthful boy's close relatives and uncles grant their accounts of Father Flynn, a distinctive picture is painted in our heads than when the youthful boy depicts him. We see that there was a relationship between them that the grown-ups felt was exceptionally odd. The more the boy considers approximately Father Flynn, the more he realizes that undoubtedly there was something unbalanced approximately him. His overthinking eventually leads him into not being able to talk when he and his close relative visit the sisters. This story is vital since it is Joyce's pundit on society and religion. The storyteller proposes that Father Flynn himself kicked the bucket of paralysis. The women depicted by Joyce are all old, sympathizing and mourning women, whose identities and lives are defined in accordance with the males of their lives. Nannie and Eliza, the two old sisters of Reverend James Flynn, are shown as two quite desperate and clueless women. They are "ignorant and ill-educated, naive, and somewhat fatuous" and the objective of their lives has been nothing but looking after their 
Reverend brother. Although "barred from the dominant discourse, they express gentle sympathy for a brother whom they tried to protect from the assaults of a perilous world." (15)

All that concerns them for the time being is whether they had been caring enough or even better said whether other people notice whether they had been caring enough of the dead brother. As Eliza mentions while smoothing her dress, "Ah poor James. God knows we done all we could as poor as we are-we wouldn't see him want anything while he was in it" (16) and their guest who is trying to comfort them mentions "Well, Miss Flynn, at any rate it must be great comfort for you to know that you did all you could for him. You were both very kind to him I must say." (15)

Although one may argue that due to the condition of death and sorrow that exists in the story, temporary paralysis is a normal state. Nevertheless one cannot ignore the fact that Joyce has chosen a story with a mourning ambience to be the starter of his masterpiece. By doing so, Joyce has laid the framework for his depiction of the paralysis and its consequential mourning from the beginning of his series of short stories. This sense of mourning, paralysis, and in times moaning continues throughout the book in a way that one cannot manage to ignore the melancholic atmosphere throughout the entire book of Dubliners. Henke beautifully observes the connection between the text of Dubliners and Joyce's own feeling of melancholy over the paralysis of his society: "The verbal puzzles initially announced in "The Sisters" by the words "gnomon," "simony," and "paralysis" are eventually revealed as symbols that haunt the textual unconscious of the narrative." (16)

In "The Sisters", the character of Nannie is depicted as a character whose personality is clumsy. This clumsiness shows itself in the way she dresses and interacts with people. As the narrator boy describes her. "I noticed how clumsily her skirt was hooked at the back and how the heels of her cloth boots were trodden down all to one side." (D 14) Elsewhere after Nannie pours her guests sherry, she sits behind her sister, which can also be considered as a sign of her passiveness. Furthermore we see the peak of her inappropriate behavior when she leans her head against the soft pillow and seems to fall asleep in front of her guests. Eliza tries to correct the situation by saying "That's poor Nannie. She's wore out." ( 16)

This pattern of unengaged or shallowly engaged women with society that is stereotyped by the character of Nannie is repeated in many of the female characters of Dubliners. As Henke points out: "When females in the story attempt to speak, their words are usually reduced to vacuous gibberish. Unable to master patriarchal discourse, they function as servants to the cultural imperatives that circumscribe their lives." (Henke 15) this form of 'vacuous gibberish' is seen in the mutterings of the Flynn sisters with their guest, while the boy narrator of the story has clearly been able to master the 'dominant discourse', and describes the story despite his young age.

Eliza, Nannie's sister, who Nannie hides behind and relies on for support, is herself another example of paralysis. As mentioned before, her entire life had been dedicated not to herself and her own growth, but to caring for her brother. Now that the brother is gone nothing remains for her own identity except a memory of a care that has been taken by the grasp of death. Even in mourning for the lost care, Eliza's dialogue with the narrator's mother is shallow, gossipy, and regressive. Eliza tries to put the whole blame on the incident when the chalice was broken.

In this way she in projecting the blame on to another party releasing herself from any possible doubt of inefficiency in taking care of her brother. Nothing new can be seen in the dialogue. 
No form of learning is taking place. In his first story, 'the sisters', Joyce uses Dublin as a country whose citizens have a strong belief in religion that they have become slaves to it (Foster 35).

The disturbing dreams of the young narrator reveal the impact that the ideological conflict between

Mr Cotter and Father Flynn are having upon his sense of identity:

In the dark of my room I imagined that I saw again the heavy grey face of the paralytic. I drew the blankets over my head and tried to think of Christmas. But the grey face still followed me. It murmured; and I understood that it desired to confess something. I felt my soul receding into some pleasant and vicious region; and there again I found it waiting for me. (Joyce 9)

James Flynn has lost his personal identity in the mind of the young narrator: he now refers to the priest as "it" and "the grey face." The young narrator is losing grip upon his previously firmly held convictions.

\subsection{The Role of Social Identity in "The Araby"}

Since the city of Dublin did not exist in a literary sense nor have any power as an Irish cultural force, Joyce creates Dublin, as it were, through the power of art. Seamus Deane's understanding of Joyce:

For the Dublin, the Ireland, he wrote of was, in an important sense, a nowhere, a territory not yet represented, a place caught between geography and history. The socializing agency in Joyce [...] is displaced from the territory, or the nation, to the action of representing it. Representation becomes the process by which a place that had been misrepresented or not represented at all finally achieves presence. This is not simply a means by which politics becomes aestheticized. It involves, first, a replacement of the political by the aesthetic, a manoeuvre through which sociality is 'restored' to the aesthetic realm from which the political had filched it. Second, the aesthetic, now complete-in-itself, re-absorbs the political. The onus of distribution has been altered. Not only is the aesthetic hierarchically superior; it also confers on the political the sociality it would illegitimately crave for itself, as its own possession." (20)

In the modern age, life has completely changed and the city has become a modernized one. This latter is the epitome of such change that has a great effect upon the modern life, bringing with it the trauma and frustration of modern failure. In this way, by the turn of the century Northern Ireland has become an arena of stillness and stagnation .Due to many factors such as the English pressure and the atrocities of the modern era great changes have altered the stream of Irish society, leading to spiritual void as well as social paralysis. . Many characters in Dubliners suffer from paralysis that affects their ability to change their lives and break there circle of routine that defer their dreams. Some examples of lack of social identity can be seen in the story "Araby". In this story we are introduced to three woman characters. The first and major character is the subject of the boy's love. The other character plays the minor role of the boy's aunt. Finally there is the stall attendant's character that leads into a frustrating epiphany for the boy narrator. All of these characters represent the subject of paralysis in different ways. The subject of the boy's love and the stall attendant of the Araby bazaar represent a form of the results of paralysis when later on in the story it is revealed that they are both merely objects of sex. Women who are mere objects of sex in this story. 
However, the boy's aunt can be studied as an example of paralysis. Although she is introduced briefly by a few sentences, there is enough information to make an informed guess about her character. When the boy mentions for the first time that he intends to go to the Araby market, the aunt is surprised and hopes "it was not some Freemason affair." (32) As it is later on realized in the story, the Araby market is an exotic and rather sexual place of gathering, full of teahouses and showrooms. This by virtue is rather different from the political objectives of the Freemason movement. The aunt's ignorance of this fact shows a level of lack of social information that would suit our definition of paralysis.

Later on, in the night of the boy's great adventure to the Araby market, the aunt entertains Mrs. Mercer who is described as "an old garrulous woman, a pawnbroker's widow, who collected used stamps for some pious purpose" ( 33 ) who the boy describes as having "to endure the gossip of the tea-table" ( 33 ). Gossip in and out of itself is another example of paralysis. It can be concluded that the lack of an informative and empowering dialogue leads to the creation of gossip.

As another sign of the aunt's paralyzed behavior, after the prolongation of the boy's uncle's arrival the aunt says "I'm afraid you may put off your bazaar for this night of our Lord" (33) which show a sign of religiosity. Religion by virtue is not a sign of paralysis; however, when it is used as a scapegoat and as an alternative answer for questions that have nonreligious answers, it is a sign of unwillingness to search for the alternative answers and thus an example of inability to move. In this case the reason for the boy's delay in departure is not because of the 'night of the Lord' but due to the uncle's delay and the aunt's blaming the 'night of the Lord' for this issue could be seen as a sign of inability or unwillingness to mention the real alternative explanation.

Women suffered a reinforced effect of the paralysis as a result of their traditionally recessive societal roles. As Henke points out, in James Joyce `s Dubliners:

Women and children have been relegated to the margins of discourse in a culture that is male -centered and woman -avoidant. Barred from communal iteration they cannot articulate desire, communicate feeling, or valorize emotional need. (Henk 12)

\subsection{The Role of Social Identity in "An Encounter"}

In Dubliners, Ireland is described as a dreary place without any hope. The characters' identities are in a state of paralysis. Talking about culture and culture area, the importance of mapping, as one of the ways which has been common to clarify culture and its elements is noteworthy. Mapping an area in a specific culture, for sure, is located under the domain of "cultural geography" about which Mark J. Smith in his book Culture: Reinventing the Social Sciences states that:

Cultural geography considers the formation of identities in relation to space and place.

The way we see ourselves in relation to the places where we live, work and play is itself a complex product of the boundaries we construct between ourselves and others.

The kinds of boundaries we draw have had an impact through the inclusion and exclusion of others. (116)

He continues to explain that, "cultural geography also assumes that 'culture' involves constant struggles for dominance and generation of resistance through which identities are accomplished" (ibid). What Smith tries to clarify is the close connection among place, culture, and identity in a way that a special place has a culture of its own which creates the 
special identity of its residents; as a result, any power which tries to dominate it will create a form of clash which leads to the resistance of its residents. The resistance is, for sure, because of the identity which has been constructed over many years and unable to be changed overnight. He, likewise, tries to explain the connection between culture and the effect of hegemony while it is used to approach culture. He believes that, "by approaching culture through the use of the idea of hegemony, culture can be conceptualized as a space within which struggles between social forces are conducted" (Mark J. Smith 81).

Antonio Gramsci, an Italian Marxist, uses hegemony, "...the assumptions, values, and meanings that shape meaning and define reality for the majority of people in a given culture" (Bressler 198), in a way that it- hegemony- plays an important role in the way culture continues its existence. By creating especial priorities for especial, mainly upper class or dominant groups in a society, culture highly affects the way people should treat one another or behave in a community. It is also very significant to notice the role of history in the formation of culture. History has always been an important element in the formation of the 'heritage' of culture. Judy Giles and Tim Middleton, elaborating on the relationship of culture and history, believe that, history is "a key practice in the processes of culture" (91). And view it "as one aspect of culture and identity" (Giles and Middleton 92). They, further, continue to explain on the role of history, mentioning that, "history is one of the ways in which human beings acquire identities and make sense of the world and their experiences of it. Thinking about how the past is represented, and how ideas about it are communicated, in the present can offer insights into the process by which meaning is produced and circulated" (Giles and Middleton 91-92).

In "An Encounter", the readers can also recognize the theme of paralysis within the characters. The characters in this story yearn for an escape outside of their boring routine ridden lives. They seek new adventures and when they try to leave their routines behind they end up turning their back on their new adventure instead. Young school boys in the story skip school one day to go on an adventure $\mathrm{n}$ effort to create excitement in their life. This is a concept that James writes about often and can be seen as a critic of the society he lived in. Many of the characters in the stories often lose their selves or remain in isolation for the rest of their lives because they never change their circle of routine. They often miss out on new opportunities, love or fulfilling their dreams because they are paralyzed with the overthinking they do. This is no exception for the boys in "An Encounter". The day they skip school to seek a more adventurous day, they head into Dublin to visit "The Pigeon House". Their day is going well until they are confronted with a weird old man. He engages in a conversation with the boys that gives him creepy presences amongst the boys. He asks them are they have any "sweethearts" and talks about what he likes about girls. Right away the boys feel uneasy and even give out fake names in order to protect their identity when talking to the man. The conversation becomes even more odd when he tells Mahony that he fantasizes being able to whip him. The narrator of the story is in a state of paralysis as a result of the conversation with the man. His speech is literally paralyzed and he does not know what to make of the conversation. This shows that going to Dublin and meeting the stranger was a disruption of routine in a negative way and caused the narrator to yearn for his old routine again. This one encounter ruined the narrators want for change in his life. He realized that maybe it is best for him to keep his life the same. This is James' way of telling the readers that we will encounter situations that make us uncomfortable but every situation should not affect our 
decisions for change in our lives. This is something that many characters face in the book. They all have desires but they do not pursue their desires because of the fear disrupting routine brings. One thing that Joyce felt is that in order for one to be successful they must leave Dublin. Perhaps he wanted to be a demonstration of that himself because he left the country after a self-imposed exile. This is interesting because some of the characters in his book long for getting out of Dublin as well.

\section{Conclusion}

This paper intended to analyze concept of social identity within Cultural Materialism framework and looked upon their influence and active interaction in building up of society and culture. The concepts of identity is addressed and revealed through the many gaps in narrative and dialogue found within each of the short stories. What this chapter attempts to address is the reading of James Joyce's Dubliners in terms of the writer's vision of Ireland from exile and understanding his vision from the perspective of looking for identity. Identity, the ideologies of self and other are represented in the way the characters understand themselves, pointing out the lingering effects of colonial stereotypes in Ireland made by the British. What the characters show is a sort of internalization of these stereotypes made by the British. Colonial Britain deemed to be Irishness; cultural incompetence and their incapability of being "British". Lack of awareness or control is typical of the stories of Dubliners. All stories indicate that the unconscious characters, caught in a repressive culture have lost visions and are haunted by limitations of living and dying. They seem incapable of finding their ways out towards a better future and intimate understanding of each other. Indirectly, Joyce turns our attention towards the social, spiritual or personal collapse of lingering characters who suffer moral uncertainty accompanied with lack of identity and selfglorification. Each character's quest, if there is any, is doomed to inertia making the paralytic paradigm of Ireland that is represented in the repetitions and cyclical patterns of the stories. Women are enclosed by the dominance of the rigid patriarchal society.

\section{References}

Abrams, M. H. A Glossary of Literary Terms. New York: Harcourt Brace Pub, 1993. Barker, Chris. Cultural Studies: Theory and Practice. London: Sage publication Inc, 2004.

Barler, Chris. Sage Dictionary of Cultural Studies. London: Sage Pub Inc, 2003.

Bei, Xu. On Reproducing Literary Style of Dubliners in Chinese, a Thesis, Shanghai International Studies University, November, 2008.

Bulson, Eric. The Cambridge Introduction to James Joyce. Cambridge: Cambridge Press, 2006.

C. E. Bressler. Literary Criticism: An Introduction to Theory and Practice. The USA: PearsonPrentice Hall, 2007.

Claire, Kilroy. An Introduction to today's Irish Novelists. Dublin: Ireland Literature Exchange, 2010.

Daronkolahee, Esmaeel Najar. James Joyce's Usage of Diction in Representation of Irish Society in Dubliners: the Analysis of "The Sisters" and "The Dead" in Historical 
Context, The Journal of International Social Research Volume: 5 Issue: 23, Fall 2012. PP. 169-174.

DeVault, Christopher M., Love and Socialism in Joyce's "A Painful Case": A Buberian Reading, TCD library electronicdatabase, 2013.

Fargnoli, Nicholas A. and Gillespie, Michael P., Critical Companion to James Joyce: A Literary Reference to His Life andWork, Infobase Publishing, New York 2006.

Freese, Lee and Burke, Peter J. Persons, Identities, and Social Interaction, Department of Sociology, Washington State University. Advances in Group Processes, Vol.11. Greenwich, Conn.: JAI Press.

Greenblatt, Stephen. Culture in Critical Terms for Literary Studies. London: Faber and Faber, 2012

Harris, Marvin. Cultural Materialism: the Struggle for a Science of Culture, Walnut Creek, California: AltaMira Press, 2001.

(https://www.google.com/search?q=Harris,+Marvin.+Cultural+Materialism)

Hamlin, Madeleine. Geographies of Mobility in James Joyce'sDubliners, Literary Geographies, Vol.2, No. 2, Syracuse University, 2016. PP. 128-143.

Harris, Marvin. The Rise of Anthropological Theory: A History of Theories of Culture, Walnut Creek, California: Alta Mira Press, 2001.

Howard, J. The new historicism in renaissance studies, in new historicism and renaissance drama, eds. Richard Dutton and Richard Wilson. London: Longman, 1992.

Joyce, James. Dubliners: Authoritative Text, Contexts, Criticism. Ed. Margot Norris. New York: W.W. Norton, 2006.

J. Giles and T. Middleton. Studying Culture: A Practical Introduction. The USA: Wiley, 2008.

Kearney, Martin F., Robert Emmet's Rising of 1803 and the Bold Mrs. Kearney: James Joyce's 'A Mother' as Historical.London.1981.

Kiberd, Declan. Inventing Ireland. London: Random House, 1995. Print.

Inglis, Tom.Local .Belonging, Identities and Sense of Place in Contemporary Ireland, in the Discussion Series: Politics and Identity No. 4, Institute for British-Irish Studies University, College Dublin, 2005.

Kuznar, Lawrence A. and Sanderson, Stephen K. "Marvin Harris's CulturalMaterialism and Its Legacy", Boulder, London: Paradigm Publishers, 2007.

Lozowski, Przemyslaw and Jarosz, Izabela. In Search of Cultural and Personal Experience behind woman in James Joyce's Dubliner, Artes Humanae, Vol. 1, 2016. PP. 157-174.

Milner, Andrew. Re-imagining Cultural Studies: The Promise of Cultural Materialism, London: SAGE Publications Ltd, 2002.

Moore, Jerry D. Marvin Harris. Cultural Materialism, Visions of Culture: An Introduction to Anthropological Theories and Theorists (2nd ed.), Walnut Creek, CA: AltaMira Press, 2004. pp. 203-215.

M. J. Smith. Culture: Reinventing the Social Sciences. Philadelphia: Open University Press, 2000.

Nazarieh, Mehrdad. James Joyce Dubliners: How Religion Influences Conscience, The Clarion: International Multidisciplinary Journal, Volume 5, 2016. PP 102-106.

Norris, M. Suspicious Reading of Joyce's Dubliners. Philadelphia: University of Pensylvania Press, 2003 
Pereira, Vijay and Malik, Ashish. The Identities of Emerging and Developed Multinational Corporations and their effect on business and society, Journal of Race, Culture and Identity. Australia.

Prendergast, Christopher. Cultural Materialism: On Raymond Williams, Volume 9. London, Minneapolis: University of Minnesota Press, 1995.

Roughley, Alan. James Joyce And Critical Theory: An Introduction. Ann Arbor: University of Michigan, 1991.

Shrum, L. J., et al., Reconceptualizing materialism as identity goal pursuits: Functions, processes, and consequences, Journal of Business Research, 2012.

Suzuki, Talashi, Epiphanies in Dubliners, P 75-81.

Taglieri, Gina. 1996. James Joyce's Dubliners. United States of America: University of New York

Ward, Todd. A. Raymond Eastman, \& Chris Ninness, An Experimental Analysis of Cultural Materialism: The Effects of Various Modes of Production on Resource Sharing Behavior and Social Issues, 18, 2009. PP. 58-80.

Williams, R. Marxism and literature. New York: Oxford University Press, 1977.

Williams, Trevor L. Resistance to Paralysis in Dubliners, MFS Modern Fiction Studies Project MUSE. Web. 05 Mar. 2013. 